\title{
Dispersion of the epigeic fauna groups in the agricultural landscape
}

\author{
Vladimír Langraf ${ }^{1 *}$, Kornélia Petrovičová ${ }^{2}$ Zuzana Krumpálová ${ }^{3}$, \\ Andrea Svoradová ${ }^{4}$, Janka Schlarmannová ${ }^{1}$
}

${ }^{1}$ Department of Zoology and Anthropology, Faculty of Natural Sciences, Constantine the Philosopher University in Nitra, Tr. A. Hlinku 1, 94976 Nitra, Slovakia

${ }^{2}$ Department of Environment and Zoology, Faculty of Agrobiology and Food Resources, Slovak University of Agriculture in Nitra, Tr. A. Hlinku 2, 94976 Nitra, Slovakia

${ }^{3}$ Department of Ecology and Environmental Sciences, Faculty of Natural Sciences, Constantine the Philosopher University in Nitra, Tr. A. Hlinku 1, 94976 Nitra, Slovakia

${ }^{4}$ Research Institute for Animal Production in Nitra, National Agricultural and Food Centre, Hlohovecká 2, 95141 Lužianky, Slovakia

\begin{abstract}
Langraf, V., Petrovičová, K., Krumpálová, Z., Svoradová, A., Schlarmannová, J., 2021. Dispersion of the epigeic fauna groups in the agricultural landscape. Folia Oecologica, 48 (2): 147-155.

Changes in the structure of epigeic animal groups indicate ecological stability, which are influenced by urbanization, agriculture, and forestry. The aim of the paper was to assess the impact of agrarian land in the vicinity of urban and suburban landscape and non-fragmented forest in the vicinity of rural landscape on the occurrence of epigeic groups. We recorded the pitfall traps - 19, 676 individuals belonging to 20 taxonomic groups at 9 localities representing 7 types of habitat. Our results indicate a year-on-year increase in the number of individuals of epigeic groups in the city, with surrounding agrarian land. We found a correlation between eudominant epigeic groups of Aranea and Hymenoptera and rural landscape with the non-fragmented surrounding. Coleoptera has shown a link between the conditions of urban and suburban landscape with the surrounding developed agriculture. We confirmed a statistically significant effect for luminosity $(p=0.002)$, humidity $(\mathrm{p}=0.025)$ and $\mathrm{pH}(\mathrm{p}=0.017)$.
\end{abstract}

\section{Keywords}

agriculture, epigeic groups, Slovakia, spatial modelling

\section{Introduction}

Agronomy is the most common environmental technology, which has positive and negative impacts on the soil. Mantreated agricultural land has a disrupted course of natural processes and poorer biodiversity compared to natural ecosystems (pedocompaction and erosion) (KaLIVODA et al. 2010; TiEMAn et al., 2015; ViCian et al. 2011, 2018). At present, the problems of negative anthropogenic influences, which have resulted in devastation and degradation of the environment, are coming to the fore.

An important part of biocenosis is zooedaphone, the presence or absence of which indicates a burden on ecosystems. Soil communities play an important role in the decomposition of organic matter, in the cycle of biogenic elements of carbon, nitrogen, sulfur, phosphorus, as well as in the transformation and degradation of waste and toxic substances. Therefore, soil organisms are important

\footnotetext{
*Corresponding author:
} 
in the terms of the sustainability of the soil ecosystem (FAZEKAŠOví and BoBULOVSKÁ, 2012).

Disruption of the environment causes a biocenosis reduction and therefore, serves as a bioindicator of the environment (PoRHAJAŠOvá et al., 2018). Groups of soil invertebrates are affected by changes in habitat conditions, e.g. spiders or beetles respond quickly to changed conditions by adjusting the structure of their assemblages (BrussaARD et al., 2007; KrumpÁlova, 2002; KrUMPÁLOVA et al., 2009). Assemblages of Araneae, Carabidae, Diplopoda and Julida are sensitive to the application of insecticides, pesticides and changes in $\mathrm{pH}$, soil moisture (CARCAMo and SPEnCE, 1994; VARVARA, 2010; Vician et al. 2015; KozAK et al., 2020). They are also important in the transformation of organic substances (TEOFILOVA, 2021). The biodiversity of epigeic groups depends on abiotic and biotic factors, characteristic of the habitat.

Agrarian land is characterized by a strong human influence such as tillage, inputs of organic and chemical fertilizers, cultivation and crop rotation, which leads to a reduction in edaphic groups (BARANová et al., 2013). In general, faunistic and floristic biodiversity is negatively affected in agricultural areas (BAVEC and BAVEC, 2014). Sustainable farming systems should be biologically and ecologically balanced, economically efficient and technically manageable. Yield increase is associated with the application of inorganic, organic fertilizers and pesticides in agroecosystems, which affects the presence or absence of fauna (ČERNÝ et al., 2019). Anticipating the interactions of biodiversity, the complexity of agroecosystems and global change resulting from the acceleration and integration of stressed land use (ZimMERER, 2010). Abundance and species richness are declining, mainly due to human activity (disturbance, fragmentation and degradation of the environment, global climate change, etc.). In the context of climate change, changes affecting agricultural production can be expected. Traditional farming systems can help modern farming systems withstand climatic extremes more easily. The findings of this practice point to the resilience of agroecosystems compared to traditional ecosystems. Effective diffusion of agro-ecological technologies largely determines how well and quickly farmers adapt to climate change (Altieri et al., 2015; Eliášoví et al., 2019). Organic farmers maintain but also improve the vitality of the soil, thereby supporting the activity and biodiversity of soil organisms. The above factors increase the demand for organic farming worldwide. Biodiversity loss has become a global problem, as the reduction of soil biodiversity negatively affects the overall performance of ecosystems. It is therefore necessary to pay attention to the decline of soil biodiversity and soil communities (YADAV et al., 2013; WAGG et al., 2014).

The aim of this study was to analyze the dispersion of epigeic groups in the urban and suburban landscape with surrounding agrarian landscape and in rural conditions with the surrounding continuous forest. We evaluated the working hypotheses: 1) in more stable rural conditions, more epigeic groups will be associated with the surrounding continuous forest stand; 2) in unstable urban and suburban conditions, fewer epigeic groups will be associated with the surrounding use of agrarian land.

\section{Materials and methods}

\section{Sampling}

Epigeic groups were collected from April to October 2015-2017 in 9 localities representing 7 types of biotopes, classified according to Stanoví and Valachovič (2002). The following crops were grown in the adjacent area of sites 4, 5, 6, 7, 8 and 9: wheat, barley, sunflower, maize and rape. In the contact area of sites 1, 2 and 3 were nongrown crops. We used pitfall traps $(750 \mathrm{ml})$ (NováK et al., 1969) which were arranged at each biotope in a trap line, and each trap line consisted of five pitfall traps (at $10 \mathrm{~m}$ intervals, a total of $50 \mathrm{~m}$ ), totalling 45 pitfall traps. The material was collected in regular three-week intervals. As a killing agent, a $4 \%$ formalin solution was used. The obtained material was determined and modified according to the nomenclature of epigeic groups by MAJZLAN (2009); POKORNÝ (2004).

\section{Study area}

The study sites are located in the geomorphological units Stolické vrchy and Juhoslovenská kotlina basin (the southern part of Central Slovakia). Location data and habitat names of the areas are shown in Table 1.

We selected 9 study sites. The first place (locality 1) was on the biotope Culture of Picea abies, and is characterised by black berries (Rubus fruticosus agg.) During the year 2016, a small number of trees - which the great spruce bark beetles (Ips typographus) has attached - were finally cut. There were no fields around the habitat. The second research plot (locality 2) was on the meadow biotope with the predominance of Arrhenatherum elatius, Alopecurus pratensis, Trisetum flavescens and Festuca rubra. Mowed twice a year, there were no fields in the vicinity of the habitat. The third place (locality 3 ) was on the nitrophilous habitat waterside vegetation characteristic of Carduus in the Salix and Tilia undergrowth. Without modification of riparian vegetation with an age of 5 years, there were no fields in the vicinity of the habitat. The fourth place (locality 4) was on the 50-60 years old Carpathian oakhornbeam forest. There was a predominance of Carpinus betulus, Robinia pseudoacacia, Quercus robur and Q. petraea. A thin shrub layer consisted of Ligustrum vulgare, Euonymus europaeus and especially the seedlings Carpinus betulus, Robinia pseudoacacia and Quercus robur, up to the height of $3 \mathrm{~m}$. There were wheat and maize fields around the habitat. The fifth research plot (locality 5) was on a biotope pasture with a predominance of Trifolium repens, Carex hirta, Cynosurus cristatus and Festuca pratensis. Grazed pasture around the habitat was enriched by the wheat and maize fields. The sixth place (locality 6) was characterized by Gallium sp. in the Salix sp. and Tilia sp. undergrowth on the nitrophilous waterside vegetation habitat, without modification of riparian vegetation with 
Table 1. Location data of the study localities

\begin{tabular}{|c|c|c|c|c|c|c|}
\hline Geomorphological unit & & Localities & C.a. & $\mathrm{m}$ asl & Landscape & Biotope \\
\hline \multirow{3}{*}{ Stolické vrchy } & 1 & Lichovo & Utekáč & 518 & Rural & Culture of Picea abies \\
\hline & 2 & Lichovo & Utekáč & 556 & Rural & Meadow \\
\hline & 3 & Farkaška & Utekáč & 446 & Rural & $\begin{array}{c}\text { Nitrophilous waterside } \\
\text { vegetation }\end{array}$ \\
\hline \multirow{6}{*}{$\begin{array}{l}\text { Juhoslovenská kotlina } \\
\text { basin }\end{array}$} & 4 & Kúpna hora & Poltár & 300 & Suburban & $\begin{array}{c}\text { Carpathian } \\
\text { oak-hornbeam forest }\end{array}$ \\
\hline & 5 & Prievranka & Poltár & 272 & Suburban & Pasture \\
\hline & 6 & Pažit' & Poltár & 218 & Suburban & $\begin{array}{c}\text { Nitrophilous waterside } \\
\text { vegetation }\end{array}$ \\
\hline & 7 & pri L'adove & Lučenec & 258 & Urban & $\begin{array}{c}\text { Carpathian turkey oak } \\
\text { forest }\end{array}$ \\
\hline & 8 & Zajačie brehy & Lučenec & 208 & Urban & Fallow field \\
\hline & 9 & Ladovo & Lučenec & 207 & Urban & $\begin{array}{c}\text { Nitrophilous waterside } \\
\text { vegetation }\end{array}$ \\
\hline
\end{tabular}

C. a., Cadastral area; $\mathrm{m}$ asl, metres above sea level.

an age of 10 years. There were wheat and rape fields in the vicinity of the habitat. The seventh place (locality 7 ) is the Carpathian turkey oak forest, which is $80-100$ years old. This tree zone is represented by species of Acer campestre, Carpinus betulus, Quercus cerris, Q. robur. Dentaria bulbifera, Corydalis spp. and Galium aparine which dominate in the herb zone. Intensive forest tree cutting took place during the years 2016 and 2017. Wheat, barley, sunflower, maize and rape fields were located around the habitat. The eighth place (locality 8 ) was on a fallow field habitat with a predominance of Arrhenatherion elatioris and Festuca pratensis. Without vegetation modification, with an age of 5 years, there were wheat, barley, sunflower, maize and rape fields around the habitat. The ninth place (locality 9) was characteristic of Gallium sp. in the Salix sp. and Tilia sp. undergrowth on the nitrophilous waterside vegetation habitat. Without modification of riparian vegetation with an age of 10 years, there were wheat, barley, sunflower, maize and rape fields in the vicinity of the habitat.

\section{Database quality}

The data quality of the obtained research data was ensured by a Microsoft SQL Server 2017 database (Express Edition), consisting of frequency tables for collections, measured environmental variables $(\mathrm{pH}$, humidity, luminosity). The database also consisted of code tables for localities and their variables (habitat, locality name, cadastral area, altitude, coordinates of localities), species and their bioindication characteristics. Matrices for statistical calculations were programmed using Microsoft SQL Server Management (SSMS).

\section{Statistical analyses}

Spatial modelling was performed by multivariate analysis Redundancy Analysis (RDA, SD $=1.20$ was on the 1 st ordination axis), with which we look for dependencies between 1) objects (epigeic groups) and rural, suburban, urban landscape, 2) objects (epigeic groups) and environmental variables $(\mathrm{pH}$, moisture, luminous intensity) between the years 2015-2017. We tested the statistical significance with the Monte Carlo permutation test (permutation 499) in the Canoco program5 (TER BraK and Śmilauer, 2012). The analysis in the statistical program Statistica Cz. Ver. 7.0 was focused on ShapiroWilks W test, which the normality of data distribution (number of individuals epigeic group) was tested. Friedman test (ANOVA) and Turkey's-HSD test (posthoc) to test the differences in the number of individuals epigeic group between years 2015-2017 and areas (rural, suburban, urban landscape) was used.

\section{Results}

In total, we recorded 19,676 individuals belonging to 20 taxonomic groups in the studied area. In the rural environment, we obtained 6,504 individuals belonging to 19 taxonomic groups. Coleoptera (42.65\%), Araneae (19.03\%) and Hymenoptera (18.34\%) were eudominant. The suburban environment was represented by 7,695 individuals and 20 taxonomic groups. The following taxonomic groups Coleoptera (47.89\%), Araneae (21.07\%) and Orthoptera $(17.65 \%)$ were eudominant. In the urban environment, we recorded 5.477 individuals belonging to 18 taxonomic groups. Coleoptera (56.31\%), Hymenoptera $(17.73 \%)$ and Araneae (10.19\%) were eudominantly represented (Table 2).

Spatial modelling of studied localities of the epigeic group, during the years 2015-2017 based on the number of individuals, was determined by redundancy analysis (RDA, SD $=1.20$ was on the 1 st ordination axis). The values of the explained cumulative variability of species data were $25.2 \%$ on the 1 st ordination axis and $39.1 \%$ on the 2 nd ordination axis. The cumulative variability of the species set explained by environment variables was 
Table 2. Distribution of the epigeic groups in the study sites

\begin{tabular}{|c|c|c|c|c|c|c|c|c|}
\hline \multirow{2}{*}{ Epigeic groups } & \multicolumn{2}{|c|}{ Rural } & \multicolumn{2}{|c|}{ Suburban } & \multicolumn{2}{|c|}{ Urban } & \multicolumn{2}{|c|}{ Total } \\
\hline & ind. & $\mathrm{D}(\%)$ & ind. & $\mathrm{D}(\%)$ & ind. & $\mathrm{D}(\%)$ & $\sum$ ind. & $\mathrm{D}(\%)$ \\
\hline \multicolumn{9}{|l|}{ Arachnida } \\
\hline Acarina & 34 & 0.52 & 12 & 0.16 & 12 & 0.22 & 58 & 0.29 \\
\hline Araneae & 1,238 & 19.03 & 1,621 & 21.07 & 558 & 10.19 & 3,417 & 17.37 \\
\hline Opilionidea & 66 & 1.01 & 92 & 1.20 & 239 & 4.36 & 397 & 2.02 \\
\hline \multicolumn{9}{|l|}{ Crustacea } \\
\hline Collembola & 19 & 0.29 & 16 & 0.21 & - & 0.00 & 35 & 0.18 \\
\hline Isopoda & 63 & 0.97 & 4 & 0.05 & - & 0.00 & 67 & 0.34 \\
\hline \multicolumn{9}{|l|}{ Diplopoda } \\
\hline Julida & 117 & 1.80 & 76 & 0.99 & 80 & 1.46 & 273 & 1.39 \\
\hline Polydesmida & 279 & 4.29 & 13 & 0.17 & 20 & 0.37 & 312 & 1.59 \\
\hline \multicolumn{9}{|l|}{ Chilopoda } \\
\hline Lithobiomorpha & 40 & 0.62 & 33 & 0.43 & 49 & 0.89 & 122 & 0.62 \\
\hline \multicolumn{9}{|l|}{ Insecta } \\
\hline Coleoptera & 2,774 & 42.65 & 3,685 & 47.89 & 3,084 & 56.31 & 9,543 & 48.50 \\
\hline Dermaptera & 51 & 0.78 & 23 & 0.30 & 38 & 0.69 & 112 & 0.57 \\
\hline Diptera & 219 & 3.37 & 126 & 1.64 & 153 & 2.79 & 498 & 2.53 \\
\hline Hemiptera & 1 & 0.02 & 5 & 0.06 & 1 & 0.02 & 7 & 0.04 \\
\hline Hymenoptera & 1,193 & 18.34 & 557 & 7.24 & 971 & 17.73 & 2,721 & 13.83 \\
\hline Lepidoptera & - & 0.00 & 1 & 0.01 & 3 & 0.05 & 4 & 0.02 \\
\hline Orthoptera & 261 & 4.01 & 1,358 & 17.65 & 184 & 3.36 & 1,803 & 9.16 \\
\hline \multicolumn{9}{|l|}{ Annelida } \\
\hline Haplotaxida & 84 & 1.29 & 4 & 0.05 & 13 & 0.24 & 101 & 0.51 \\
\hline \multicolumn{9}{|l|}{ Gastropoda } \\
\hline Stylommatophora & 11 & 0.17 & 6 & 0.08 & 10 & 0.18 & 27 & 0.14 \\
\hline \multicolumn{9}{|l|}{ Mammalia } \\
\hline Anura & 2 & 0.03 & 38 & 0.49 & 19 & 0.35 & 59 & 0.30 \\
\hline Insectivora & 26 & 0.40 & 10 & 0.13 & 14 & 0.26 & 50 & 0.25 \\
\hline Rodentia & 26 & 0.40 & 15 & 0.19 & 29 & 0.53 & 70 & 0.36 \\
\hline$\sum$ individuals & 6,504 & 100 & 7,695 & 100 & 5,477 & 100 & 19,676 & 100 \\
\hline
\end{tabular}

ind., individuals.

represented in the first ordination axis $57.2 \%$ and in the 2nd axis $88.8 \%$. We identified a statistically significant effect of rural $(\mathrm{p}$-value $=0.0126)$, suburban $(\mathrm{p}$-value $=$ $0.0144)$, urban ( $\mathrm{p}$-value $=0.0374$ ) landscape, for the epigeic groups of the localization under examination. The selected environment variables were not mutually correlated with the maximum value of the inflation factor $=2.9464$. The significance test of all axes was $p$-value $=$ 0.0196 . The ordination graph (triplot) contained epigeic groups ordered into 2 clusters (Fig. 1).

The first cluster formed the epigeic groups Acarina, Dermaptera, Diptera, Haplotaxida, Hymenoptera, Insecti- vora, Isopoda, Polydesmida and Rodentia, preferring rural landscape conditions. The landscape was characterized by the surrounding continuous forest.

The second cluster consisted of Anura, Hemiptera, Lepidoptera, Lithobiomorpha, Opilionidae and Stylomatophora correlated with urban landscape and surrounding agricultural land.

The third cluster consisted of Araneae, Coleoptera, Collembola, Julida, Orthoptera correlated with suburban landscape and surrounding agricultural land.

Spatial modelling of study localities of the epigeic group, during the years 2015-2017 based on the number of 


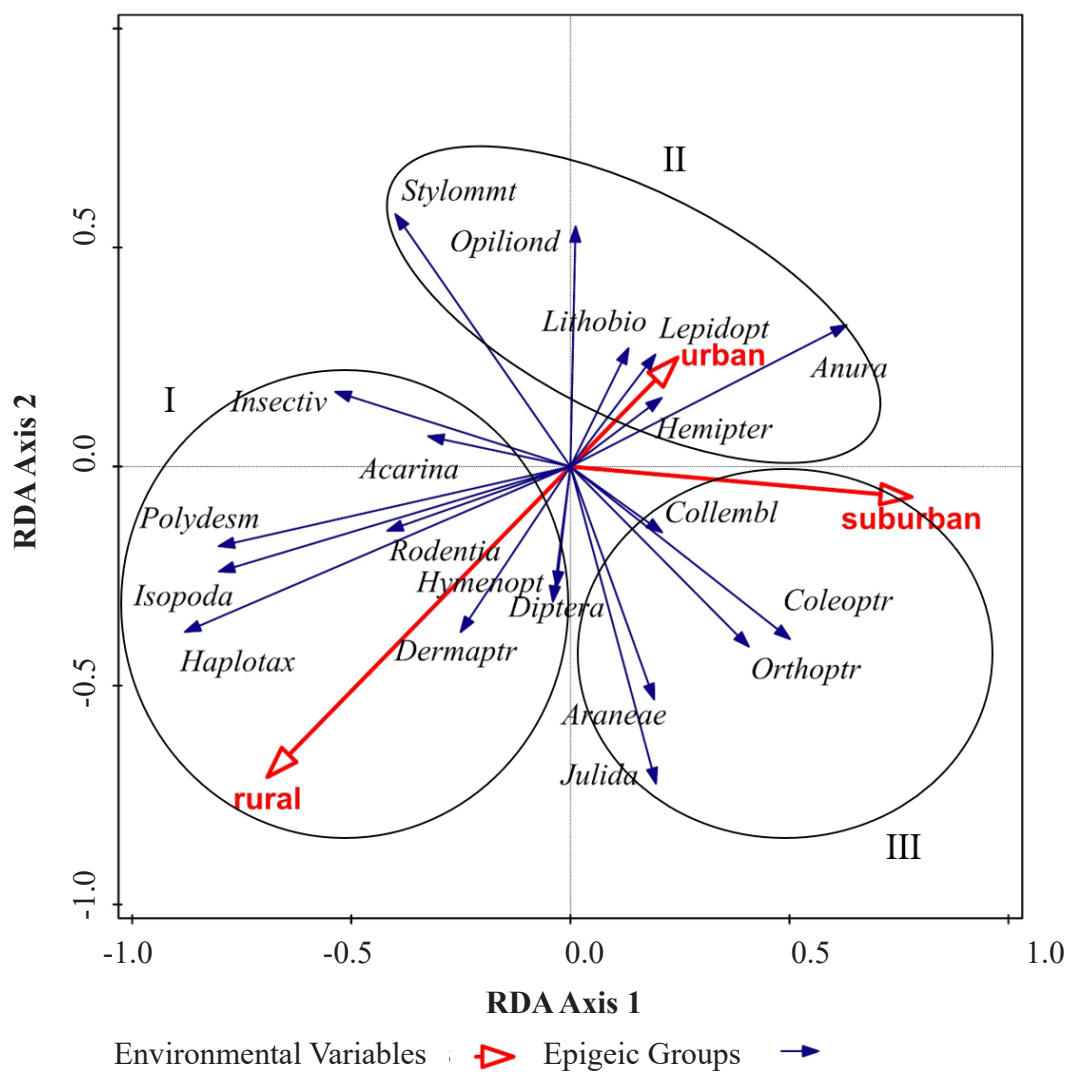

Fig. 1. RDA analysis of epigeic groups of researched sites.

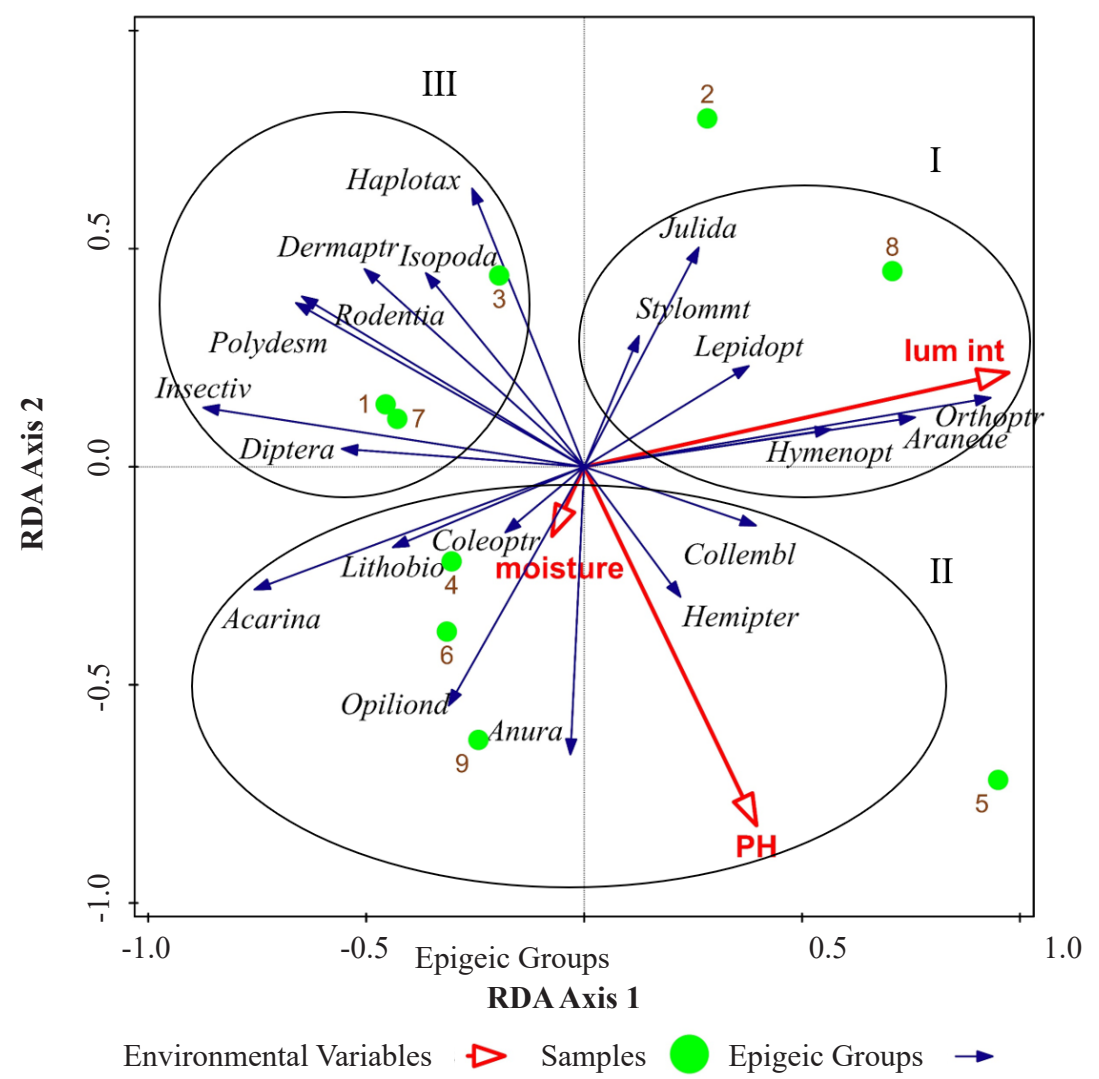

Fig. 2. RDA analysis of epigeic groups and environment variables (luminous intensity, moisture, $\mathrm{pH}$ ). lum int, luminous intensity. 
individuals, was determined by RDA analysis. The values of the explained cumulative variability of species data are $39.8 \%$ on the 1 st ordination axis and $52.7 \%$ on the 2 nd ordination axis. The cumulative variability of the species set explained by environment variables is represented in the 1 st ordination axis $64.3 \%$ and in the 2 nd axis $85.2 \%$. We identified a statistically significant effect of luminous intensity $(p$-value $=0.002)$, moisture $(p$-value $=0.025)$ and $\mathrm{pH}$ ( $\mathrm{p}$-value $=0.017)$, for the epigeic groups of the localitions under examination. The selected environment variables were not mutually correlated with the maximum value of the inflation factor $=1.1353$. The significance test of all axes is p-value $=0.006$. The ordination graph (triplot) contains epigeic groups ordered into 3 clusters (Fig. 2).

The first cluster formed the epigeic groups Araneae, Hymenoptera, Julida, Lepidoptera, Orthoptera and Stylomatophora, which affects luminous intensities.

The second cluster are represented by epigeic groups influenced by $\mathrm{pH}$ or monsture. The following advice are Acarina, Anura, Coleoptera, Collembola, Hemiptera, Lithobiomorpha and Opilionidae.

The third cluster consisted of Dermaptera, Diptera, Haplotaxida, Insectivora, Isopoda, Polydesmida and Rodentia, which are not affected by the variables $\mathrm{pH}$, luminous intensity and monsture.

The normality data distribution (EV) was violation $(\mathrm{p}$-value $=0.00)$, based on the fact we used a nonparametric Friedmanov test (ANOVA) to confirm the statistically significant difference $(p$-value $=0.0244)$ (Fig. 3) of individuals, between rural, suburban and urban landscape during the years 2015-2017. Using a post-hoc test (Turkey's-HSD), we identified which landscapes (rural, suburban, urban) differed between 2015 and 2017 at the level of statistical significance $p=0.05$ (Table 3). The results showed an increase in the average value of individuals in rural and suburban conditions for 2016 and a subsequent decline for 2017. In the urban landscape, we found an increase between 2015 and 2016 and maintained a similar average value for 2017. Based on the above, it can be concluded that with the increase in intensive usage of the surrounding agricultural landscape, the average number of epigeic groups in the urban and suburban landscape is also growing.

\section{Discussion}

Epigeic groups living in anthropogenic landscape have a wider tolerance than the epigeic group of natural habitats. They also achieve high local density due to agriculture and urbanization (ALBERTI et al., 2017; MAgura et al., 2020). We recorded the total eudominant representation in the epigeic groups Araneae, Coleoptera and Hymenoptera. The high abundance of these groups influences the maintenance of the natural balance and substance cycle of the biogenic elements carbon, nitrogen, sulfur and phosphorus, in ecosystems; Peterková (2004).

$F(4.962)=0.12760, p=0.024497$

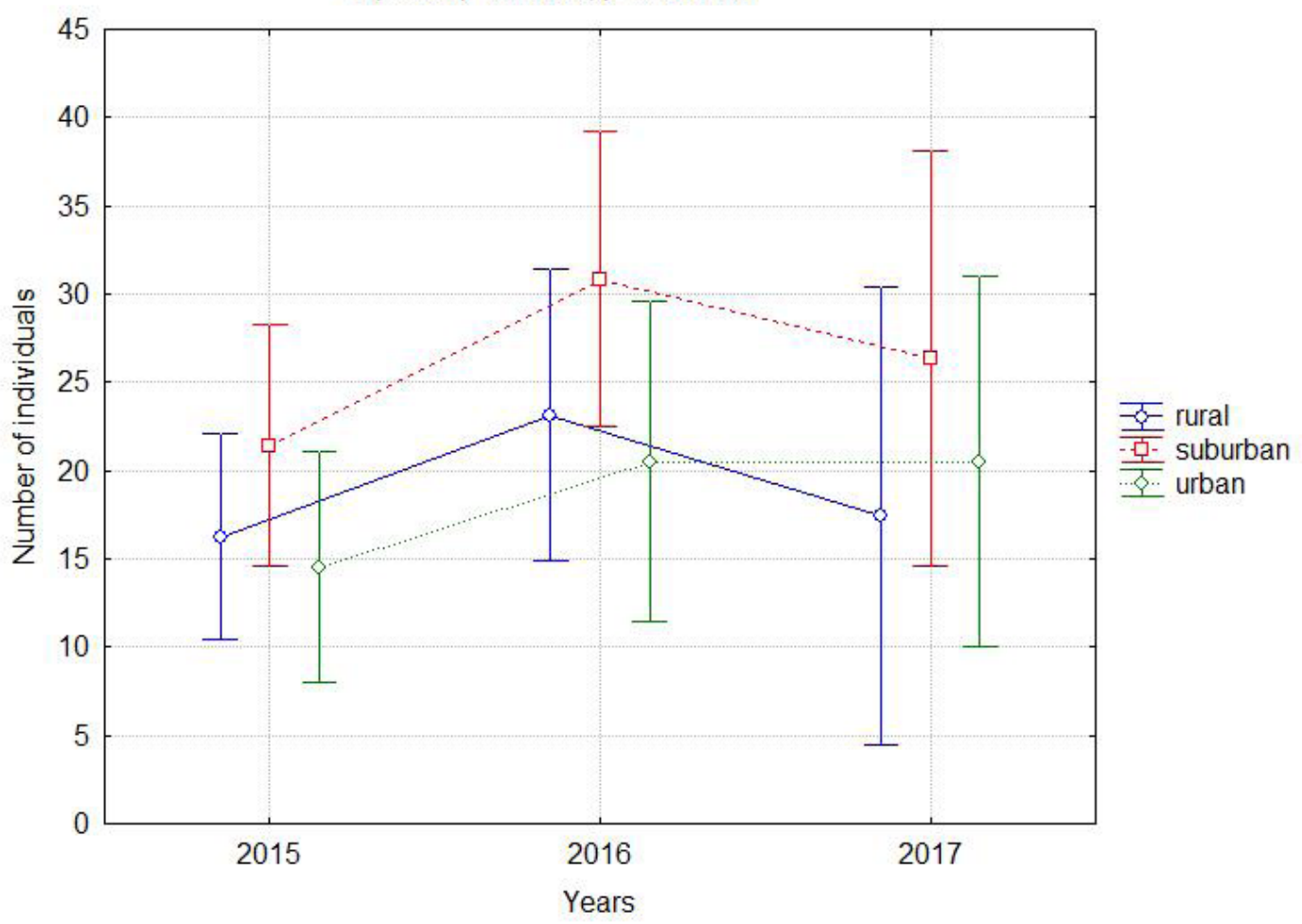

Fig. 3. Analysis of variance (Friedman test (ANOVA)) of average number of individuals values. 
Table 3. Results of Post hoc test in P-level

\begin{tabular}{ccccccccccc}
\hline & 1 & 2 & 3 & 4 & 5 & 6 & 7 & 8 & 9 \\
\hline 1 & - & 0.018 & 0.874 & 0.258 & 0.005 & 0.013 & 0.702 & 0.437 & 0.487 \\
2 & 0.018 & - & 0.462 & 0.752 & 0.201 & 0.661 & 0.011 & 0.672 & 0.697 \\
3 & 0.874 & 0.462 & - & 0.590 & 0.048 & 0.315 & 0.699 & 0.699 & 0.715 \\
4 & 0.258 & 0.752 & 0.590 & - & 0.049 & 0.477 & 0.015 & 0.875 & 0.885 \\
5 & 0.005 & 0.201 & 0.048 & 0.049 & - & 0.546 & 0.003 & 0.010 & 0.013 \\
6 & 0.013 & 0.661 & 0.315 & 0.477 & 0.546 & - & 0.085 & 0.440 & 0.466 \\
7 & 0.702 & 0.011 & 0.699 & 0.015 & 0.003 & 0.085 & - & 0.294 & 0.344 \\
8 & 0.437 & 0.672 & 0.699 & 0.875 & 0.010 & 0.440 & 0.294 & - & 0.999 \\
9 & 0.487 & 0.697 & 0.715 & 0.885 & 0.013 & 0.466 & 0.344 & 0.999 & - \\
\hline
\end{tabular}

1 , rural in the year 2015; 2 , rural in the year 2016; 3, rural in the year 2017; 3, suburban in the year 2015; 4, suburban in the year 2016; 5, suburban in the year 2017; 7, urban in the year 2015; 8, urban in the year 2016; 9, urban in the year 2017.

Holecova et al. (2003) confirmed that the Hymenoptera (Formicidae) group is dominant. Their activities accelerate the decomposition of plant residues, aerate the soil and improve soil structure and quality. The epigeic groups Araneae, Coleoptera and Orthoptera were represented by eudominants in rural and urban conditions with the surrounding agricultural land. LENOIR and LENNARTSSON (2010) found the same fact in agrarian land. Coleoptera represent the dominant group of soil macrofauna, reacting rapidly to anthropogenic activities BoHÁč et al. (2015). The Carabidae family from the Coleoptera family is most often used as a bioindicative. They are also sensitive to insecticides, pesticides, $\mathrm{pH}$, soil moisture and to the excessive use of artificial fertilizers (CARCAMO and SPENCE, 1994; LöVEI and SundERLAND, 1996; Vician et al., 2015; TIEMAN et al., 2015). In spatial modelling, we noted the correlation of Coleoptera on the conditions of the suburban landscape with the surrounding agrarian landscape and also the statistically significant effect of moisture on this group.

Subdominant representation related to rural landscape (continuous forest in the vicinity) was recorded in the groups Acarina, Dermaptera, Diptera, Insectivora, Isopoda, Julida, Polydesmida and Rodentia. Subdominant and subrecedent representation with correlation to urban and suburban conditions (intensively used agricultural land in the vicinity) was confirmed in Anura, Collembola, Haplotaxida, Hemiptera, Lepidoptera, Lithobiomorpha, Opilionidea and Stylommatophora. Despite the low presence of these groups, their importance in the ecosystem is irreplaceable. They not only contribute to the biodiversity of agrarian land, but also to ecological stability. The intensively used agrarian landscape provides a different spectrum of fauna, which represents a diversified component of the soil fauna. These epigeic groups are characterized by different adaptations to the soil environment and sensitivity to stress. The abundance and biodiversity of these epigeic groups supports the natural conditions of ecosystems (SWAMINATHAN, 2014; FAZEKašoví and Bobulovská, 2012). LitavskÝ et al. (2018) confirmed that the presence of epigeic groups in different types of ecosystems is related to trophic preference and is linked to habitat conditions. Gormsen et al. (2006) confirmed that the termination of agricultural treatments is associated with an increase of the Acarina population. From our results, we also confirmed the connection of Acarina to the rural landscape without the surrounding agrarian land. Collembola populations are affected by vegetation, soil conditions and organic fertilizers which have a positive effect on population growth (JASINSKI et al., 2016). From the results, we proved the link to the suburban and urban landscape with the surrounding agricultural land and confirmed the effect of $\mathrm{pH}$ and moisture on this group. Based on the above, we can conclude that the fields in the agricultural landscape (suburban area, urban) are fertilized organically.

The increase in the average value of an individual for 2016 and 2017 in the conditions of an urban landscape with the surrounding agriculturally used landscape is probably related to suitable climatic conditions and a sufficient food supply. Porhajašová (2017) pointed out the same fact in the conditions of agroecosystems.

\section{Conclusion}

Spatial modelling revealed the connection of eudominant epigeic groups Araneae (17.37\%) and Hymenoptera $(13.83 \%)$ to the conditions of the rural landscape with the surrounding continuous forest. Coleoptera (48.50\%) correlated to suburban and urban landscape with the surrounding intensively used agricultural landscape. Based on the above facts, it can be concluded that the some species of epigeic groups Araneae, Hymenoptera and Coleoptera are suitable for a bioindicative assessment of the state of the landscape. A statistically significant effect was confirmed at luminous intensity ( $p$-value $=$ 0.002 ) on the eudominant lines Araneae, Hymenoptera and moisture $(\mathrm{p}$-value $=0.025), \mathrm{pH}(\mathrm{p}$-value $=0.017)$ acting on the Coleoptera dispersion. Year-on-year changes point to an increase in the average number of epigeic groups in the conditions of the agrarian landscape and suburban 
landscape. Epigeic groups may be used for landscape planning documents, which is something the study will look into in the future.

\section{Acknowledgements}

This research was supported by the grants VEGA 1/0604/20 Environmental assessment of specific habitats in the Danube Plain, KEGA No. 019UKF-4/2021 Creation and innovation of education - Zoology for Ecologists, part - Invertebrates.

\section{References}

Alberti, M., Marzluff, J., Hunt, V.M., 2017. Urban driven phenotypic changes: empirical observations and theoretical implications for eco-evolutionary feedback. Philosophical Transactions of The Royal Society B: Biological Sciences, 372: 2-9. https://doi.org/10.1098/ rstb.2016.0029

Altieri, M.A., Nicholls, C.I., Henao, A., Lana, M.A., 2015. Agroecology and the design of climate changeresilient farming systems. Agronomy for Sustainable Development, 35: 869-890. https://doi.org/10.1007/ s13593-015-0285-2

Baranová, B., Fazekašová, D., Jászay, T., Manko, P., 2013. Ground beetle (Coleoptera: Carabidae) community of arable land with different crops. Folia Faunistica Slovaca, 18: 21-29.

BAVEC, M., BAVEC, F. 2014. Impact of organic farming on biodiversity. In Lo, Y.H., Blanco, J.A., Shovonlal, R. (eds). Biodiversity in ecosystems. Linking structure and function. Rijeka: Intech, p. 185-202.

Brussard, L., Ruiter, P.C., Brown, G.G., 2007. Soil biodiversity for agricultural sustainability. Agriculture, Ecosystems \& Environment, 121: 233-244. https://doi. org/10.1016/j.agee.2006.12.013

BoнÁč, J., Jahnová, Z., 2015. Land use changes and lanscape degradation in Central and Eastern Europe in the last decades: epigeic invertebrates as bioindicators of landscape changes. In Armon, R., Hanninen, O. (eds). Environmental indicators. Dordrecht: Springer, p. 395 419.

Carcamo, H.A., Spence, J.R., 1994. Crop type effects on the activity and distribution of ground beetles (Coleoptera, Carabidae). Environmental Entomology, 23: 684-692. https://doi.org/10.1093/ee/23.3.684

ČernÝ, I., PaČuta, V., Ernst, D., Marek, J., Gažo, J., Šulík, R., Bušo, R., 2019. Yield and quality of sugar beet depending on variety and growing conditions of year. Listy Cukrovarnícke a Řepařské, 135: 204-208.

Eliášová, M., ŠišKa, B., Kollár, J., Ďuricová, V., 2019. Vplyv poveternostných podmienok na formovanie spoločenstiev bystrušiek rodu Carabus na lesnom stanovišti na lokalite Bábsky les [The influence of weather condition on the forming of carabus beetles coenoses on the forest stand at the locality Bábsky les]. In RoŽNOvsKÝ, J., Litschmann, T. (eds). Extrémy počasí, jejich dopady a bezpečnostní rizika. Broumov, 8. - 10. 10. 2019. Praha: Český hydrometeorologický ústav, p. 21-27.

FAZekašová, D., Bobulovská, L., 2012. Soil organisms as an indicator of quality and environmental stress in the soil ecosystem. Životné Prostredie, 46: 103-106.

Gormsen, D., Hedlung, K., Wang, H.F., 2006. Diversity of soil mite communities when managing plant communities on set-aside arable land. Applied Soil Ecology, 31: 147158. https://doi.org/10.1016/j.apsoil.2005.03.001

Holecová, M., Lukáš, J., Harakalová, E., 2003. Mravce (Hymenoptera, Formicidae) dubovo-hrabových lesov v okolí Bratislavy (JZ Slovensko) [Ants (Hymenoptera, Formicidae) of oak-hornbeam forest in a vicinity of Bratislava (SW Slovakia)]. Folia Faunistica Slovaca, 8: 63-69.

JASInSKi, M., Twardowski, J., TendZiagolska, E., 2016. The occurrence of soil mesofauna in organic crops. Journal of Research and Applications in Agricultural Engineering, 61: 193-199.

Kalivoda, H., Petrovič, F., Kalivodová, E., Kürthy, A., 2010. Influence of the landscape structure on the butterfly (Lepidoptera, Hesperioidea and Papilionoidea) and bird (Aves) taxocoenoses in Vel'ké Leváre (SW Slovakia). Ekológia (Bratislava), 29: 337-359.

Kozak, V.M., Romanenko, E.R., Brygadyrenko, V.V., 2020. Influence of herbicides, insecticides and fungicides on food consumption and body weight of Rossiulus kessleri (Diplopoda, Julidae). Biosystems Diversity, 28 : 272-280. https://doi.org/10.15421/012036

Krumpálova, Z., 2002. Epigeic spiders (Araneae) of one Middle Danube floodplain forest. Biologia, Bratislava, 57: 161-169.

Krumpálova, Z., KrumpáL, M., ŠtrbíK, I., 2009. Classification of epigeic spiders (Araneae) at the western part of the Carpathians (Slovakia). Biologia, Bratislava, 64: 116123. https://doi.org/10.2478/s11756-009-0018-6

Lenoir, L., Lennartsson, T., 2010. Effects of timing of grazing on arthropod communities in semi-natural grasslands. Journal of Insect Science, 10: 33-42. https:// doi.org/10.1673/031.010.6001

Litavský, J., Stašıov, S., Svitok, M., Michalková, E., MajZlan, O., ŽARnOvičan, H., Fedor, P., 2018. Epigeon communities of harvestmen (Opiliones) in Pannonian Basin floodplain forests: an interaction with environmental parameters. Biologia, Bratislava, 73: 753-763. https:// doi.org/10.2478/s11756-018-0084-8

LöveI, G.L., Sunderland, K.D., 1996. Ecology and behavior of ground beetles (Coleoptera: Carabidae). Annual Review of Entomology, 41: 231-256.

Magura, T., Ferrante, M., Lövei, L.G., 2020. Only habitat specialists become smaller with advancing urbanization. Global Ecology and Biogeography, 29: 1978-1987. https://doi.org/10.1111/geb.13168

MajZlan, O., 2009. Bezchordáty a chordáty [Non-chordates and chordates]. Bratislava: Danubiaprint, a.s. 286 p.

Microsoft SQL Server 2017. (RTM) - 14.0.1000.169 (X64) Aug 222017 17:04:49 Copyright (C) 2017 Microsoft Corporation Express Edition (64-bit) on Windows 10 Home $10.0<$ X64> (Build 18362:). 
Novák, K., Balát, F., Bartoš, E., BoučEK, Z., Daniel, M., Dlabola, J., DoskočIl, J., Holman, J., HrbáčeK, J., Agemann, E., Kunst, M., Landa, V., LANG, J., MaŘan, J., Miller, F., Nosek, J., Novák, K., Obenberger, J., Obr, S., Pelikán, J., Raušer, J., Rosický, B., Rusek, J., Schwarz, J., SkuhravÝ, V., Slouková, M., ŠllhavÝ, V., ŠTys, P., TeYrovskÝ, V., VONDrÁČEK, K., ZAhradníK, J., ZelenÝ, J., 1969. Metody sběru a preparace hmyzu [Methods for collecting and preserving insects]. Praha: Academia. 243 p.

Peterková, V., 2004. Dynamika výskytu bystruškovitých $\mathrm{v}$ alternatívnom spôsobe pestovania plodín [Dynamic of occurence of Carabidae in alternative soil utilization]. Acta Facultatis Paedagogicae Universitatis Tyrnaviensis. Séria. B-prírodné vedy, 8: 11-13.

PokornÝ, V., ŠIfNer, F., 2004. Atlas hmyzu [An atlas of insects]. Praha: Paseka. 221 p.

Porhajašová, J., 2017. Aktivita a priestorová štruktúra epigeických skupin v závislosti od aplikácie organických hnojiv v podmienkach agroekosystémov [Activity and spatial distribution of epigeic groups depending on application of organic fertilizers under agroecosystem conditions]. Nitra: Slovenská polnohospodárska univerzita. $61 \mathrm{p}$.

Porhajašová, J., Babošová, M., Noskovič, J., ONDrišík, P., 2018. Long-term developments and biodiversity in carabid and staphylinid (Coleoptera: Carabidae and Staphylinidae) fauna during the application of organic fertilizers under agroecosystem conditions. Polish Journal of Environmental Studies, 27: 2229-2235. https:// doi.org/10.15244/pjoes/77072

Stanová, V., Valachovič, M. (eds), 2002. Katalóg biotopov Slovenska [Habitat catalogue of Slovakia]. Bratislava: DAPHNE - Inštitút aplikovanej ekológie. 225 p.

Statsoft, inc., 2004. Statistica Cz [Softwarový systém na analýzu dat]. Verze 7. [Data analysis software system]. Version 7. [cit. 2020-10-19]. http://www.statsoft.cz/

Swaminathan, R., 2014. Ground beetles (Coleoptera: Carabidae): their potential as bioagents in agroecosystems. Basic and Applied Aspects of Biopesticides, 12: 225-233.

Teofilova, T., 2021. The ground beetles (Coleoptera: Carabidae) and their role as bio-agents. Forest Science. Special Issue, 125-142.
Ter Braak C.J.F., Šmilauer P., 2012. Canoco reference manual and user's guide: software for ordination, version 5.0. Ithaca USA: Microcomputer Power. 496 p.

Tieman, L.K., Grandy, A.S., AtKinson, E.E., MarinSpiotta, E., McDaniel, M.D., 2015. Crop rotational diversity enhances belowground communities and functions in a agroecosystem. Ecology Letters, 18: 761771.

Varvara, M., 2010. The genus Carabus (Coleoptera, Carabidae) in some potato crops from Romania. Oltenia. Studii şi Comunicări Ştiinţele Naturii, 26: 137-146.

Vician, V., Stašıov, S., Kočík, K., Hazuchová, L., 2011. The structure of community Coleoptera: Carabidae on various farmed areas in the Podpol'anie region and their indication. Acta Facultatis Ecologiae, 24-25: 123-131.

Vician, V., Svitok, M., Kočík, K., StašIov, S., 2015. The influence of agricultural management on the structure of ground beetle (Coleoptera: Carabidae) assemblages. Biologia, Bratislava, 70: 240-251. https://doi. org/10.1515/biolog-2015-0028

Vician, V., Svitok, M., Michalková, E., Lukáčik, I., StAŠIOV, S., 2018. Influence of tree species and soil properties on ground beetle (Coleoptera: Carabidae) communities. Acta Oecologica, 91: 120-126. https://doi. org/10.1016/j.actao.2018.07.005

WagG, C., Bender, S.F., Widmer, F., Heidden, M.G.A., 2014. Soil biodiversity and soil community composition determine ecosystem multifunctionality. Proceedings of the National Academy of Sciences, 111: 5266-5270. https://doi.org/10.1073/pnas.1320054111

Yadav, S., Singh, Y., Yadav, M.K., Babu, S., Singh, K., 2013. Effect of organic nutrient management in basmati rice (Oryza sativa) - based cropping systems. Current Advances in Agricultural Sciences, 5: 50-54.

Zimmerer, K.S., 2010. Biological diversity in agriculture and global change. Annual Review of Environment and Resources, 35: 137-166. 